\title{
Good Government Governance, Gaya Kepemimpinan dan Kinerja Manajerial Penyelenggara Pemerintahan Desa
}

\section{Gusti Ayu Agung Yustika Nanda ${ }^{1}$ \\ Fakultas Ekonomi dan Bisnis Universitas Udayana, Indonesia}

\section{Gusti Ayu Made Asri Dwija Putri² \\ Fakultas Ekonomi dan Bisnis \\ Universitas Udayana, Indonesia}

\section{Surel : y
BSTRAK}

Penelitian ini bertujuan untuk menguji pengaruh penerapan Good Government Governance serta gaya kepemimpinan terhadap kinerja manajerial penyelenggara pemerintahan desa di Kabupaten Badung. Berdasarkan hasil analisis ditemukan bahwa variabel Good Government Governance serta gaya kepemimpinan secara simultan berpengaruh signifikan terhadap kinerja manajerial. Hal ini menunjukkan bahwa semakin baiknya penerapan Good Government Governance dan gaya kepemimpinan yang tepat maka akan semakin baik kinerja manajerial. Good Government Governance secara parsial berpengaruh signifikan terhadap kinerja manajerial. Hal ini menunjukkan bahwa adanya tata kelola pemerintahan yang baik dapat meningkatkan kinerja manajerial. Gaya kepemimpinan juga secara parsial berpengaruh signifikan terhadap kinerja manajerial. Hal ini menunjukkan bahwa gaya kepemimpinan yang tepat dapat meningkatkan kinerja manajerial. Good Government Governance perlu diterapkan untuk menjaga hubungan baik dengan masyarakat dalam kegiatan terkait pemerintahan desa. Kata Kunci: Good Government Governance; Gaya

Kepemimpinan; Kinerja Manajerial.

\section{Good Government Governance, Leadership Style and Managerial Performance of Village Government Organizers}

\begin{abstract}
This study aims to examine the effect of the implementation of Good Government Governance and leadership style on managerial performance of village government administrators in Badung Regency. Based on the results of the analysis it was found that the variables of Good Government Governance and leadership style simultaneously had a significant effect on managerial performance. This shows that the better the implementation of Good Government Governance and the right leadership style, the better managerial performance will be. Good Government Governance partially has a significant effect on managerial performance. This shows that the existence of good governance can improve managerial performance. Leadership style also partially has a significant effect on managerial performance. This shows that the right leadership style can improve managerial performance.

Keywords: Good Government Governance; Leadership Style; Managerial Performance.
\end{abstract}

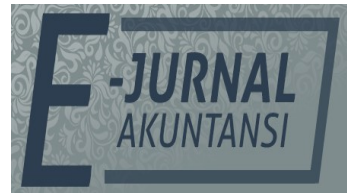

e-ISSN 2302-8556

Vol. 31 No. 8

Denpasar, Agustus 2021

Hal. 1999-2010

DOI:

10.24843/EJA.2021.v31.i08.p10

PENGUTIPAN:

Nanda, I.G.A.A.Y., \& Putri, I.G.A.M.A.D. (2021).

Government Governance, Gaya Kepemimpinan dan Kinerja Manajerial Penyelenggara Pemerintahan Desa. E-Jurnal Akuntansi, 31(8), Hal. 19992010

RIWAYAT ARTIKEL: Artikel Masuk: 8 Oktober 2019 Artikel Diterima: 1 November 2019

Artikel dapat diakses : https://ojs.unud.ac.id/index.php/Akuntansi/index 


\section{PENDAHULUAN}

Menurut Wiratno et al, (2013) penilaian kinerja sangat penting bagi organisasi atau lembaga untuk dapat menilai keberhasilan dari upaya yang telah dilaksanakan dalam rangka mencapai visi, misi dan strateginya. Suatu organisasi akan berhasil dalam mencapai tujuan dan program-programnya bila orang yang bekerja dalam organisasi tersebut dapat melakukan tugasnya dengan baik sesuai dengan bidangnya dan tanggungjawabnya (Putra et al, 2013). Mangkunegara dalam Putra et al (2013) menyebutkan kinerja adalah hasil kerja secara kualitas dan kuantitas yang dicapai oleh seorang pegawai dalam melaksanakan tugasnya sesuai dengan tanggungjawab yang diberikan kepadanya. Menurut Tjiptono \& Diana dalam Andriyanto (2013) menyatakan kinerja manajerial merupakan kemampuan dalam menggunakan pengetahuan, perilaku, dan bakat dalam melaksanakan tugasnya sehingga tercapai target yang diinginkan.

Kinerja manajerial penyelenggara pemerintah desa merupakan suatu gambaran mengenai tingkat pencapaian sasaran sebagai penjabaran dari visi, misi, dan tujuan instansi pemerintah desa yang mengindikasikan seberapa besar tingkat keberhasilan atau kegagalan pelaksanaan kegiatan-kegiatan sesuai dengan tugas pokok dan fungsi dari aparatur pemerintah desa tersebut (Widasari \& Putri, 2018). Tanzi dalam Onuorah \& Appah (2012) menyatakan bahwa pemerintahan yang baik merupakan bagian penting dari kerangka kerja untuk manajemen ekonomi dan keuangan. Demi mewujudkan penyelenggaraan pemerintah yang baik maka pemerintah mencoba mewujudkan pemerintahan yang bersih dan berwibawa atau dikenal dengan istilah Good Government Governance (GGG) (Azlina \& Amelia, 2014). Handi dan Bambang dalam Hutapea \& Widyaningsih (2017) menyatakan bahwa kinerja sebuah pemerintah daerah akan lebih baik bila prinsip-prinsip Good Government Governance (GGG) diterapkan pada pemerintah daerah.

Secara umum masyarakat di Indonesia menginginkan tata kelola negara dan keuangan dijalankan dengan baik, bersih, transparan dan bertanggung jawab. Good governance diartikan sebagai tata kelola yang baik pada suatu usaha yang dilandasi etika profesional dalam berusaha dan berkarya, selain itu good governancemenerangkan perangkat peraturan yang baik untuk mengatur hubungan, fungsi dan kepentingan publik (Jatmiko \& Lestiawan, 2016). Uche dalam Qadir \& Kwanbo (2012) menjelaskan struktur tata kelola organisasi menentukan hak dan tanggung jawab antara pemangku kepentingan dalam organisasi tersebut.alah satu pilihan strategis untuk menerapkan Good Government Governance (GGG) adalah melalui penyelenggaraan pelayanan publik. Menurut (Mardiasmo, 2002) terdapat 3 fungsi utama sektor publik, melakukan pelayanan publik yang sangat vital bagi kepentingan umum, mendefinisikan prinsip operasional masyarakat, dan menyediakan pelayanan publik yang diperlukan karena tidak ada sektor swasta atau nirlaba yang ingin menanganinya.

Berdasarkan penelitian Baihaqi (2010) menyatakan prinsip-prinsip Good Governance berpengaruh positif dan signifikanterhadap kinerja instansi pemerintahan. Hasil penelitian ini menunjukkan bahwa semakin baik Good Government Governance (GGG), maka kinerja pemerintah daerah semakin baik, sebaliknya Good Government Governance (GGG) yang buruk mengakibatkan kinerja pemerintah daerah yang buruk juga. Berbeda dengan penelitian yang dilakukan oleh Susanto (2015) yang menyatakan bahwa Good Governance tidak berpengaruh 
terhadap kinerja manajerial pemerintahan daerah. Keberhasilan penerapan Good Governance diduga tidak dapat tercapai tanpa peran seorang pemimpin (Daniri, 2007). Embrianto et al dalam Sugianto et al (2018) menjelaskan faktor kepemimpinan menjadi sangat penting karena dari peran pemimpin tersebut organisasi dapat menunjukkan karakter kinerjanya. Maka dari itu seorang pemimpin harus mampu mengembangkan gaya kepemimpinannya yang mampu meningkatkan kinerja pemerintah daerahnya (Wiratno et al., 2013).

Kepemimpinan adalah suatu proses dimana seseorang dapat menjadi pemimpin (leader) melalui aktivitas yang terus menerus sehingga dapat mempengaruhi yang dipimpinnya (followers) dalam rangka untuk mencapai tujuan organisasi atau perusahaan (Brahmasari \& Suprayetno, 2008). Robbins dalam Ariyawan et al (2018) menjelaskan kepemimpinan adalah kemampuan untuk mempengaruhi suatu kelompok kearah pencapaian tujuan. Gaya kepemimpinan ialah pola perilaku yang akan ditunjukkan oleh pemimpin dalam mempengaruhi orang lain atau karyawan (Satyawati \& Suartana, 2014). Gaya kepemimpinan memiliki tipe manajemen yang berbeda-beda (Warrick, 1981). Begitu pentingnya peran pemimpin sehingga isu mengenai gaya kepemimpinan menjadi fokus yang menarik perhatian para peneliti bidang perilaku keorganisasian (Raharjo \& Nafisah, 2006).

Penelitian Amertadewi \& Dwirandra (2013), Baihaqi (2010) dan Listyowati (2018) mengenai gaya kepemimpinan menyatakan gaya kepemimpinan berpengaruh secara positif dan signifikan terhadap kinerja pemerintah daerah. Hasil penelitian menunjukkan bahwa semakin tepat dan efektif gaya kepemimpinan yang diterapkan oleh seorang pemimpin maka kinerja pemerintah daerah semakin baik, sebaliknya gaya kepemimpinan yang tidak tepat dan efektif mengakibatkan kinerja pemerintah daerah yang buruk juga. Namun hasil berbeda dijelaskan pada penelitian Amri (2015) menyatakan kepemimpinan tidak berpengaruh positif signifikan terhadap kinerja. Handoko (2015) menjelaskan gaya kepemimpinan berpengaruh positif tetapi tidak signifikan terhadap kinerja. Wiratno et al (2013) menyatakan gaya kepemimpinan tidak berpengaruh positif terhadap kinerja.

Untuk melihat gaya kepemimpinan mana yang paling banyak digunakan dan paling besar pengaruhnya terhadap kinerja manajerial penelitian ini mengggunakan beberapa gaya kepemimpinan antara lain gaya kepemimpinan direktif, gaya kepemimpinan suportif, gaya kepemimpinan partisipatif dan gaya kepemimpinan yang berorientasi kepada prestasi. Maka diharapkan penelitian ini dapat menunjukkan gaya kepemimpinan yang dapat meningkatkan kinerja bawahan dimana perilaku tersebut harus dapat memuaskan kebutuhankebutuhan bawahan sehingga memungkinkan tercapainya efektivitas dalam pelaksanaan kerja (Putra et al., 2013).

Penelitian Good Government Governance (GGG), dan gaya kepemimpinan terhadap kinerja manajerial telah banyak diteliti, namun mengenai responden yang berlatar belakang pemerintahan desa sebagai pengelola dana desa sepengetahuan penulis masih sedikit yang meneliti. Dengan pertimbangan hal tersebut, penulis ingin membuktikan pengaruh kedua faktor yang mempengaruhi kinerja manajerial pada pemerintahan desa di Kabupaten Badung. 
Penerapan Good Government Governance (GGG) dapat membantu aparatur pemerintah dalam pengambilan keputusan yang efektif yang bertujuan untuk menyelaraskan kepentingan antara agent dan principal sehingga dapat meminimalkan resiko kesalahan pengambilan keputusan dan penyalahgunaan wewenang sehingga tujuan organisasi dapat tercapai. Hal ini sejalan dengan asumsi teori keagenan yang dikemukakan oleh Eisenhardt (1989) salah satunya adalah asumsi tentang sifat manusia yang bertindak oportunistik. Dengan adanya penerapan Good Government Governance (GGG) pada suatu organisasi akan mampu meminimalkan sifat oportunis dari para manajemen sehingga berdampak pada perbaikan kinerja organisasi.

Hubungan atau kontrak masih terjadi masalah agensi yang timbul karena adanya asimetri informasi antara agent dan principal. Salah satu cara yang digunakan untuk memonitor masalah kontrak dan membatasi perilaku oportunistik manajemen adalah dengan menerapkan prinsipGood Government Governance (GGG). Aisyah et al (2014) menyebutkan bahwa dengan melaksanakan Good Government Governance (GGG), salah satu manfaat yang bisa dipetik adalah meningkatkan kinerja melalui tercapainya proses pengambilan keputusan yang lebih baik, meningkatkan efisiensi operasional serta lebih meningkatkan pelayanan kepada publik.

Penelitian Baihaqi (2010) menyatakan prinsip-prinsip Good Corporate Governance (GCG) berpengaruh positif dan signifikan terhadap kinerja instansi pemerintahan. Andriyanto (2013) dan Listyowati (2018) menyatakan Good Government Governance (GGG) berpengaruh secara positif dan signifikan terhadap kinerja pemerintah daerah. Widasari dan Putri (2018) dan Budionoet al(2016) menyatakan Good Governance berpengaruh positif terhadap kinerja manajerial. Azlina dan Amelia (2014) Good Governance berpengaruh signifikan terhadap kinerja pemerintah daerah. Acintya dan Putri (2015) menyatakan Good Governance berpengaruh positif pada kinerja pemerintah. Aisyah et al (2014) Good Governace berpengaruh signifikan dan positif terhadap kinerja pemerintah daerah. Windiarto (2015) dan Fauziah (2016) menyatakan prinsip-prinsip Good Corporate Governance (GCG) berpengaruh positif terhadap kinerja aparatur pemerintahan.

Dari penjelasan di atas dapat disimpulkan bahwa penerapan Good Government Governance (GGG) dapat meningkatkan kinerja karena dengan penerapan Good Government Governance (GGG) yang baik dalam organisasi sektor publik maka dapat membantu aparatur pemerintahan dalam pengambilan keputusan yang efektif untuk menyelaraskan kepentingan antara pemberi wewenang dan penerima wewenang. Berdasarkan penjelasan tersebut, dapat ditarik hipotesis hubungan penerapan Good Government Governance (GGG) terhadap kinerja adalah sebagai berikut.

$\mathrm{H}_{1}$ : Penerapan Good Government Governance berpengaruh positif pada Kinerja Manajerial.

Salah satu faktor yang sangat penting dalam suatu organisasi yaitu gaya kepemimpinan. Gaya kepemimpinan sangat berpengaruh terhadap kinerja suatu organisasi. Apabila gaya kepemimpinan seorang manajer itu baik maka dapat meningkatkan kinerja dari organisasi tersebut. Gaya kepemimpinan berkenaan dengan cara-cara yang digunakan oleh manajer untuk mempengaruhi bawahannya. Agar dapat mempengaruhi bawahan sesuai dengan kemauan 
pemimpin maka seorang pemimpin harus mampu memberikan motivasi kepada bawahannya dalam menjalankan tugas, wewenang, dan tanggung jawab yang diberikan kepadanya.

Menurut Sholihah (2018) menyatakan bahwa gaya kepemimpinan merupakan cara pemimpin untuk mempengaruhi orang atau bawahannya sedemikian rupa sehingga orang tersebut mau melakukan kehendak pemimpin untuk mencapai tujuan organisasi meskipun secara pribadi hal tersebut mungkin tidak disenangi. Menurut Sedarmayanti (2007) gaya kepemimpinan merupakan norma perilaku yang digunakan seorang manajer pada saat ia mempengaruhi perilaku bawahannya.

Selain itu pemimpin juga dapat memberikan pujian, penghargaan, serta memberikan insentif kepada karyawan yang meempunyai kinerja yang baik (Gani, 2005). Pemimpin merupakan penentu berhasil atau tidaknya suatu organisasi. Pemimpin dapat memberikan pengaruh yang sangat besar terhadap kinerja para bawahannya. Namun Siagian dalam Trisnaningsih (2007) menyatakan bahwa tidak semua gaya kepemimpinan yang diterapkan oleh manajer dalam menjalankan tugasnya mempunyai pengaruh yang sama terhadap pencapaian tujuan perusahaan, dalam hal ini penggunaan gaya kepemimpinan yang tidak tepat oleh manajer justru akan menurunkan kinerja karyawan.

Penelitian Amertadewi \& Dwirandra (2013), Baihaqi (2010) dan Listyowati (2018) mengenai gaya kepemimpinan menyatakan gaya kepemimpinan berpengaruh secara positif dan signifikan terhadap kinerja pemerintah daerah. Sholihah (2018) menyatakan gaya kepemimpinan berpengaruh terhadap kinerja. Arumsari \& Budiartha (2016) menyatakan gaya kepemimpinan memiliki hubungan yang positif terhadap kinerja. Yogantara \& Wirakusuma (2013) menyatakan gaya kepemimpinan berpengaruh signifikan terhadap kinerja manajerial. Namun hasil berbeda dijelaskan pada penelitian Amri (2015) menyatakan kepemimpinan tidak berpengaruh positif signifikan terhadap kinerja. Handoko (2015) menjelaskan gaya kepemimpinan berpengaruh positif tetapi tidak signifikan terhadap kinerja. Wiratno et al (2013) menyatakan gaya kepemimpinan tidak berpengaruh positif terhadap kinerja.

Dari penjelasan di atas dapat disimpulkan bahwa gaya kepemimpinan dapat meningkatkan kinerja karena dengan penerapan gaya kepemimpinan yang baik dalam organisasi sektor publik maka dapat membantu meningkatkan efektifitas kinerja aparatur pemerintahan sehingga dapat memberikan pelayanan publik kepada masyarakat secara maksimal. Berdasarkan penjelasan tersebut, dapat ditarik hipotesis hubungan penerapan gaya kepemimpinan terhadap kinerja adalah sebagai berikut.

$\mathrm{H}_{2}$ : Penerapan Gaya Kepemimpinan berpengaruh positif pada Kinerja Manajerial.

\section{METODE PENELITIAN}

Lokasi pada penelitian dilakukan di 46 desa dinas di Kabupaten Badung. Penelitian ini dilakukan di Kabupaten Badung karena Kabupaten Badung merupakan organisasi sektor publik dengan anggaran dan realisasi nominal pendapatan daerah tertinggi di Bali. Berikut rincian organisasi desa Kabupaten Badung. Objek penelitian dalam penelitian ini adalah Good Government Governance (GGG), gaya kepemimpinan dan kinerja manajerial penyelenggara pemerintahan 
desa di Kabupaten Badung. Populasi dalam penelitian ini adalah apatur pemerintahan desa yang berada di 46 desa diseluruh Kabupaten Badung.

Penelitian ini mengambil sampel sebanyak 5 sampel di setiap desa yang diteliti. Analisis regresi linear berganda dalam penelitian ini digunakan untuk mengetahui pengaruh Good Government Governance (GGG), serta gaya kepemimpinan terhadap kinerja manajerial penyelenggara pemerintahan desa di Kabupaten Badung. Adapun model penelitian yang digunakan dalam penelitian ini adalah sebagai berikut.

$Y=\alpha+\beta_{1} \cdot X_{1}+\beta_{2} \cdot X_{2}+\varepsilon$

Keterangan:

Y

a

$\beta_{1-} \beta_{5}$

$\mathrm{X}_{1}$

$\mathrm{X}_{2}$

$\varepsilon$

$=$ Variabel dependen, yaitu kinerja manajerial

= Konstanta

$=$ Koefisien regresi

= Variabel independen, Good Government Governance

$=$ Variabel independen, gaya kepemimpinan

$=$ standard error

\section{HASIL DAN PEMBAHASAN}

Hasil analisis deskriptif meliputi rata-rata, standar deviasi, skor minimum, dan skor maksimum. Deskripsi skor kuesioner Good Government Governance (GGG), gaya kepemimpinan pada kinerja manajerial penyelenggara pemerintahan desa yang tersaji pada Tabel 1 .

Tabel 1. Hasil Analisis Deskriptif

\begin{tabular}{|c|c|c|c|c|c|}
\hline Variabel & $\mathrm{N}$ & Minimum & Maksimum & Rata-rata & $\begin{array}{l}\text { Standar } \\
\text { Deviasi }\end{array}$ \\
\hline $\begin{array}{l}\text { Good Government } \\
\text { Governance }\left(\mathrm{X}_{1}\right)\end{array}$ & 230 & 52,00 & 75,00 & 64,808 & 5,385 \\
\hline $\begin{array}{l}\text { Gaya Kepemimpinan } \\
\left(\mathrm{X}_{2}\right)\end{array}$ & 230 & 37,00 & 55,00 & 46,939 & 5,484 \\
\hline Kinerja Manajerial $(\mathrm{Y})$ & 230 & 34,00 & 50,00 & 42,243 & 3,740 \\
\hline
\end{tabular}

Sumber: Data Penelitian, 2019

Variabel Good Government Governance (GGG) $\left(X_{1}\right)$ memiliki nilai minimum sebesar 52,00 dan nilai maksimum sebesar 75,00 dengan nilai rata-rata sebesar 64,8087, jika dibagi dengan 15 item pernyataan akan menghasilkan 4,320 yang artinya rata-rata responden memberikan skor 4 untuk item pernyataan Good Government Governance (GGG). Nilai standar deviasi variabel Good Government Governance (GGG) adalah sebesar 5,385. Hal ini berarti standar penyimpangan data terhadap nilai rata-rata adalah 5,385.

Variabel gaya kepemimpinan $\left(X_{2}\right)$ memiliki nilai minimum sebesar 37,00 dan nilai maksimum sebesar 55,00 dengan nilai rata-rata sebesar 46,939, jika dibagi dengan 11 item pernyataan akan menghasilkan 4,267 yang artinya rata-rata responden memberikan skor 4 untuk item pernyataan gaya kepemimpinan.Nilai standar deviasi variabel gaya kepemimpinanadalah sebesar 5,484. Hal ini berarti standar penyimpangan data terhadap nilai rata-rata adalah 5,484.

Variabel kinerja manajerial ( $Y$ ) memiliki nilai minimum sebesar 34,00 dan nilai maksimum sebesar 50,00 dengan nilai rata-rata sebesar 42,243, jika dibagi dengan 10 item pernyataan akan menghasilkan 4,224 yang artinya rata-rata 
responden memberikan skor 4 untuk item pernyataan kinerja manajerial.Nilai standar deviasi variabel kinerja manajerialadalah sebesar 3,740. Hal ini berarti standar penyimpangan data terhadap nilai rata-rata adalah 3,740.

Analisis regresi linear berganda diolah dengan bantuan program SPSS (Statistic Package of Social Science) for Windows dengan hasil yang disajikan pada Tabel 2.

Tabel 2. Hasil Uji Regresi Linear Berganda

\begin{tabular}{llllll}
\hline \multirow{2}{*}{ Model } & \multicolumn{2}{c}{$\begin{array}{c}\text { Unstandardized } \\
\text { Coefficients }\end{array}$} & $\begin{array}{c}\text { Standardized } \\
\text { Coefficients }\end{array}$ & \multirow{2}{*}{ Tig. } \\
\cline { 2 - 4 } & $\mathrm{B}$ & Std. Error & Beta & & \\
\hline (Constant) & 20,030 & 2,643 & & 7,580 & 0,000 \\
Good Government & 0,192 & 0,047 & 0,276 & 4,114 & 0,000 \\
Governance (X) & 0,208 & 0,046 & 0,305 & 4,544 & 0,000 \\
Gaya Kepemimpinan $\left(\mathrm{X}_{2}\right)$ & 0,252 & & & & \\
Adjusted R2 & 39,507 & & & & \\
F Hitung & 0,000 & & & & \\
Sig. F & & & &
\end{tabular}

Dari Tabel 2, tersebut dapat dibuatkan persamaan sebagai berikut.

$$
\mathrm{Y}=20,030+0,192 \mathrm{X}_{1}+0,208 \mathrm{X}_{2}+\varepsilon
$$

Hasil pengujian hipotesis pertama menunjukkan bahwa Good Government Governance (GGG) bernilai positif terhadap kinerja manajerial. Hasil uji t sebesar 4,114 dengan tingkat signifikansi sebesar 0,000 < $\alpha=0,05$ sehingga $\mathrm{H}_{1}$ diterima, yang berarti bahwa penerapan Good Government Governance (GGG) berpengaruh positif dan signifikan terhadap kinerja manajerial penyelenggara pemerintahan desa di Kabupaten Badung.

Sejalan dengan teori agensi yang menjelaskan mengenai hubungan antara principal dan agent. Hubungan principal dan agent dapat mengarah pada kondisi ketidakseimbangan informasi karena agent memiliki lebih banyak informasi dibandingkan principal, sehingga dapat menimbulkan asimetri informasi. Menurut Eisenhardt (1989) mengenai asumsi teori keagenan adalah asumsi tentang sifat manusia, penerapan Good Government Governance (GGG) pada suatu organisasi akan mampu meminimalkan sifat oportunis dari para manajemen sehingga berdampak pada perbaikan kinerja organisasi. Salah satu cara yang digunakan untuk memonitor masalah kontrak dan membatasi prilaku oportunistik manajemen adalah dengan menerapkan prinsip Good Government Governance (GGG).

Penerapan Good Government Governance (GGG) diharapkan akan memberi arahan yang jelas pada perilaku kinerja serta etika profesi organisasi, upaya ini dimaksud agar kiprah maupun produk jasa yang dihasilkan akan lebih aktual dan terpercaya untuk mewujudkan kinerja yang lebih optimal dan lebih baik (Trisnaningsih, 2007). Penerapan Good Government Governance (GGG) sangat diyakini memberikan kontribusi yang strategis dalam menciptakan peningkatakan kinerja serta sangat efektif menghindari penyimpangan dan mencegah korupsi dan suap (Daniri, 2007).

Hasil yang diperoleh dalam pengujian hipotesis pertama mendukung hasil penelitian Wati \& Aprilla (2010) menyimpulkan bahwa Good Governance memberikan pengaruh yang positif dan signifikan terhadap kinerja auditor 
pemerintah. Hasil penelitian ini juga mendukung penelitian yang dilakukan oleh Penelitian Baihaqi (2010) menyatakan prinsip-prinsip Good Governance berpengaruh positif dan signifikanterhadap kinerja instansi pemerintahan. Andriyanto (2013) dan Listyowati (2018) menyatakan Good Government Governance (GGG) berpengaruh secara positif dan signifikan terhadap kinerja pemerintah daerah. Widasari \& Putri (2018) dan Budiono et al (2016) menyatakan Good Governance berpengaruh positif terhadap kinerja manajerial. Azlina \& Amelia (2014) Good Governance berpengaruh signifikan terhadap kinerja pemerintah daerah.

Hasil pengujian hipotesis kedua menunjukkan bahwa gaya kepemimpinan bernilai positif terhadap kinerja manajerial. Hasil uji t sebesar 4,544 dengan tingkat signifikansi sebesar $0,000<\alpha=0,05$ sehingga $\mathrm{H}_{2}$ diterima, yang berarti bahwa gaya kepemimpinan berpengaruh positif dan signifikan terhadap kinerja manajerial penyelenggara pemerintahan desa di Kabupaten Badung.

Menurut Eisenhardt (1989) mengenai asumsi teori keagenan salah satunya adalah asumsi tentang sifat manusia yang akan bertindak oportunistik. Sejalan dengan teori agensi tentang asumsi sifat manusia, gaya kepemimpinan yang sesuai dapat diterapkan dalam kinerja pemerintahan desa. Menurut teori path-Goal pimpinan bisa mengubah gaya atau perilaku mereka untuk memenuhi permintaan dari situasi tertentu. Brahmasari \& Suprayetno (2008) menyatakan bahwa gaya kepemimpinan merupakan suatu upaya untuk memengaruhi banyak orang melalui proses komunikasi untuk mencapai tujuan organisasi diharapkan dapat menimbulkan perubahan positif berupa kekuatan dinamis yang dapat mengkoordinasikan organisasi dalam rangka mencapai tujuan jika diterapkan sesuai dengan koridor yang telah ditetapkan kedua belah pihak sesuai dengan jabatan yang dimiliki.

Gaya Kepemimpinan mempunyai pengaruh memotivasi para anggota organisasi untuk lebih mengutamakan kepentingan organisasi dibandingkan individu dan berdampak pada kinerja manajerial yang baik. Dijelaskan juga di dalam teori stewardship yang menggambarkan situasi para manajer tidak termotivasi oleh tujuan-tujuan individu tetapi lebih merujuk kepada sasaran hasil utama mereka untuk kepentingan organisasi (Riyadi \& Yulianto, 2014).

Hasil penelitian ini sejalan dengan penelitian yang dilakukan Amertadewi \& Dwirandra (2013), Baihaqi (2010) dan Listyowati (2018) mengenai gaya kepemimpinan menyatakan gaya kepemimpinan berpengaruh secara positif dan signifikan terhadap kinerja pemerintah daerah. Sholihah (2018) menyatakan gaya kepemimpinan berpengaruh terhadap kinerja. Arumsari \& dan Budiartha (2016) menyatakan gaya kepemimpinan memiliki hubungan yang positif terhadap kinerja. Yogantara \& Wirakusuma (2013) menyatakan gaya kepemimpinan berpengaruh signifikan terhadap kinerja manajerial.

Koefisien determinasi menunjukkan seberapa besar pengaruh variabel bebas $(\mathrm{X})$ terhadap variabel terikat $(\mathrm{Y})$, yang ditunjukkan dengan nilai Adjusted $\mathrm{R}$ Square. Nilai adjusted $\mathrm{R}^{2}=0,252$ menunjukkan bahwa kedua variabel bebas yaitu Good Government Governance (GGG) $\left(\mathrm{X}_{1}\right)$ dan gaya kepemimpinan $\left(\mathrm{X}_{2}\right)$ berkontribusi pengaruh sebesar 25,2 persen terhadap variabel terikat yaitu kinerja manajerial penyelenggara pemerintahan desa $(Y)$ dan sisanya sebesar 74,8 persen dipengaruhi oleh variabel lain yang tidak dimasukkan dalam model penelitian. 
Hasil uji F menunjukkan bahwa nilai $\mathrm{F}$ hitung untuk variabel terikat yaitu kinerja manajerial penyelenggara pemerintahan desa (Y) sebesar 39,507 signifikansi $F=0,000$. Nilai signifikansi $F=0,000$ (sig. $F<0,05$ ) menunjukkan signifikansi pengaruh variabel-variabel bebas terhadap variabel terikat dan model penelitian adalah layak. Hasil ini memberikan makna bahwa variabel Good Government Governance (GGG) $\left(\mathrm{X}_{1}\right)$ dan gaya kepemimpinan $\left(\mathrm{X}_{2}\right)$ mampu memprediksi atau menjelaskan fenomena kinerja manajerial penyelenggara pemerintahan desa.

\section{SIMPULAN}

Good Government Governance (GGG) berpengaruh positif terhadap kinerja manajerial penyelenggara pemerintahan desa di Kabupaten Badung. Penerapan Good Government Governance (GGG) yang baik diharapkan dapat meningkatkan kinerja manajerial penyelenggara pemerintahan desa di Kabupaten Badung. Gaya kepemimpinan berpengaruh positif terhadap kinerja manajerial penyelenggara pemerintahan desa di Kabupaten Badung. Penerapan gaya kepemimpinan yang tepat dan efektif yang baik diharapkan dapat meningkatkan kinerja manajerial penyelenggara pemerintahan desa di Kabupaten Badung.

Penelitian ini dilakukan hanya pada pemerintahan desa di Kabupaten Badung, untuk penelitian selanjutnya disarankan untuk memperluas populasi dan sampel penelitian, dilakukan pada lokasi yang berbeda tidak hanya yang berada di wilayah Kabupaten Badung saja, sehingga diperoleh hasil penelitian yang tingkat generalisasinya lebih tinggi. Perbedaan tersebut memungkinkan hasil penelitian yang berbeda.

Besarnya nilai Adjusted $R$ Square dapat menjelaskan variabel terikat yang dapat dijelaskan oleh variabel bebas sebesar 25,2 persen , sedangkan sisanya 74,8 persen dijelaskan oleh variabel lainnya yang tidak dimasukkan ke dalam penelitian ini. Penelitian selanjutnya disarankan untuk menggunakan atau menambahkan variabel bebas lain yang diduga dapat berpengaruh terhadap kinerja manajerial penyelenggara pemerintahan desa antara lain partisipasi anggaran, komitmen organisasi dan motivasi karyawan.

Lingkup penelitian yang digunakan dalam penelitian ini adalah kinerja manajerial non financial (lebih kepada teknis kinerja manajerial). Penelitian selanjutnya disarankan agar melakukan lingkup penelitian terhadap kinerja manajerial yang lebih luas ( financial maupun non-financial).

\section{REFERENSI}

Abdul-qadir, A. B., \& Kwanbo, M. L. (2012). Corporate Governance and Financial Performance of Banks In The Post Consolidation Era In Nigeria. International Journal of Social Sciences and Humanity Studies, 4(2), 27-36.

Acintya, I. G. A. A. D., \& Putri, I. G. A. M. A. D. (2015). Kinerja Pemerintah Kota Denpasar Dalam Implementasi SAKIP dan Penerapan Good Governance. EJurnal Akuntansi Universitas Udayana, 12(2), 233-248.

Aisyah, S., Karmizi, \& Savitri, E. (2014). Pengaruh Good Governance, Gaya Kepemimpinan, Komitmen Organisasi dan Budaya Organisasi Terhadap Kinerja Pemerintah Daerah (Studi Pada Pemerintah Daerah Kabupaten Kampar). Jurnal Online Mahasiswa Fakultas Ekonomi Universitas Riau, 1(2), 1- 
16. https:// doi.org/10.1016/j.bbapap.2013.06.007

Amertadewi, T. I. M., \& Dwirandra, A. A. N. B. (2013). Pengaruh Partisipasi Anggaran Terhadap Kinerja Manajerial Dengan Gaya Kepemimpinan dan Locus of Control Sebagai Variabel Moderasi. E-Jurnal Akuntansi Universitas Udayana, 4(3), 550-566.

Amri, K. (2015). Pengaruh Kepemimpinan, Motivasi, Displin Kerja, dan Pelatihan Kerja Terhadap Kinerja Karayawan BTM Bina Ihsanul Fikri Yogyakarta.

Andriyanto, N. (2013). Pengaruh Pengendalian Intern dan Penerapan Prinsip Prinsip Good Corporate Governance Terhadap Kinerja Manajerial (Studi Empiris Pada PT. BRI (Persero) Tbk Cabang Jember).

Ariyawan, Y. W., Rivai, A., \& Suharto. (2018). Influence Of Leadership Style and Organizational Culture On Organizational Performance Through Job Satisfaction In PT Telekomunikasi Indonesia Tbk. The International Journal of Engineering and Science, 7(10), 21-37. https://doi.org/10.9790/18130710032137

Arumsari, A. L., \& Budiartha, I. K. (2016). Pengaruh Profesionalisme Auditor, Independensi Auditor, Etika Profesi, Budaya Organisasi, dan Gaya Kepemimpinan Terhadap Kinerja Auditor Pada Kantor Akuntan Publik di Bali. E-Jurnal Ekonomi Dan Bisnis Universitas Udayana, 5(8), 2297-2304.

Azlina, N., \& Amelia, I. (2014). Pengaruh Good Governance dan Pengendalian Intern Terhadap Kinerja Pemerintah Kabupaten Pelalawan. Jurnal Akuntansi Universitas Jember, 12(2), 32-42.

Baihaqi, M. F. (2010). Pengaruh Gaya Kepemimpinan Terhadap Kepuasan Kerja dan Kinerja Dengan Komitmen Organisasi Sebagai Variabel Intervening (Studi Pada PT. Yudhistira Ghalia Indonesia Area Yogyakarta).

Brahmasari, I. A., \& Suprayetno, A. (2008). Pengaruh Motivasi Kerja , Kepemimpinan dan Budaya Organisasi Terhadap Kepuasan Kerja Karyawan serta Dampaknya pada Kinerja Perusahaan ( Studi Kasus pada PT . Pei Hai International Wiratama Indonesia ). Jurnal Manajemen Dan Kewirausahaan, 10(2), 124-135.

Budiono, A., Fathoni, A., \& Minarsih, M. M. (2016). Pengaruh Good Governance, Pengendalian Intern dan Budaya Organisasi Terhadap Kinerja Pegawai Kantor Keuangan Kodam IV Diponegoro yang Berkedudukan di Semarang. Journal of Management, 2(2), 1-22.

Daniri, A. (2007). Good Corporate Governance: Konsep dan Penerapannya dalam Konteks Indonesia. Jakarta: PT Triexs Trimacindo.

Eisenhardt, K. M. (1989). Agency Theory : An Assessment and Review. Academy of Management Review, 14(1), 57-74.

Embrianto, P. A., Sulindawati, N. L. G. E., \& Sinarwati, N. K. (2016). Pengaruh Partisipasi Penyusunan Anggaran, Gaya Kepemimpinan Sistem Pengendalian Manajemen dan Total Quality Management Terhadap Kinerja Karyawan Dengan Locus of Control Sebagai Variabel Moderating (Studi Pada Dinas Pendapatan Kabupaten Buleleng). E-Journal S1 Akuntansi Universitas Pendidikan Ganesha, 6(3), 1-11.

Fauziah, S. (2016). Analisis Pengaruh Penerapan Prinsip-Prinsip Good Corporate Governance, Motivasi dan Budaya Organisasi Terhadap Kinerja Aparatur Pemerintahan (Studi Empiris Pada Satuan Kerja Perangkat Daerah Kota 
Surakarta). https://doi.org/https://doi.org/10.3929/ethz-b-000238666

Gani, N. (2005). Pengaruh Perilaku Pemimpin dan Kompensasi Terhadap Prestasi Kerja Guru. Jayapura.

Handoko, A. (2015). Analisis Pengaruh Penerapan Prinsip Prinsip Good Corporate Governance, Komitmen Organisasi dan Gaya Kepemimpinan Terhadap Kinerja Instansi Pemerintahan.

Hutapea, F. L., \& Widyaningsih, A. (2017). Pengaruh Good Government Governance dan Ukuran Legislatif Terhadap Kinerja Pemerintah Daerah. Jurnal Akuntansi Riset, 9(1), 173-186.

Jatmiko, B., \& Lestiawan, H. Y. (2016). Good Governance Government and The Effect On Local Government Performance (Survey On Gunung Kidul District Government of Indonesia). International Journal of Applied Business and Economic Research, 14(14), 981-997.

Listyowati, W. E. (2018). Pengaruh Partisipasi Penyusunan Anggaran, Gaya Kepemimpinan, Budaya Organisasi, dan Good Government Governance Terhadap Kinerja Pemerintah Daerah (Studi Empiris Pada SKPD Kabupaten Kulon Progo). Jurnal Mahasiswa Universitas Muhammadiyah Yogyakarta, 1-18.

Mardiasmo. (2002). Akuntansi Sektor Publik. Yogyakarta: Andi.

Onuorah, A. C.-C., \& Appah, E. (2012). Accountability and Public Sector Financial Management in Nigeria. Oman Chapter of Arabian Journal of Business and Management Review, 1(6), 1-17. https:/ / doi.org/10.12816/0002105

Putra, C. B., Utami, H. N., \& Hakam, M. S. (2013). Pengaruh Gaya Kepemimpinan Direktif, Suportif, dan Partisipatif Terhadap Kinerja Karyawan (Studi Pada PT. Astra Internasional Tbk. Daihatsu Malang). Jurnal Administrasi Bisnis (JAB), 2(2), 11-20.

Raharjo, S. T., \& Nafisah, D. (2006). Gaya Kepemimpinan Terhadap Kepuasan Kerja, Komitmen Organisasi dan Kinerja Karyawan. Jurnal Studi Manajemen $\mathcal{E}$ Organisasi, 3(2), 69-81.

Riyadi, S., \& Yulianto, A. (2014). Pengaruh Pembiayaan Bagi Hasil, Pembiayaan Jual Beli, Financing To Deposit Ratio (FDR), Dan Non Performing Financing (NPF) Terhadap Profitabilitas Bank Umum Syariah di Indonesia. Accounting Analysis Journal, 3(4), 466-474.

Satyawati, N., \& Suartana, I. (2014). Pengaruh Gaya Kepemimpinan Dan Budaya Organisasi Terhadap Kepuasan Kerja Yang Berdampak Pada Kinerja Keuangan. E-Jurnal Akuntansi Universitas Udayana, 6(1), 17-32.

Sedarmayanti. (2007). Manajemen Sumber Daya Manusia. Bandung: Refika Aditama. Sholihah, P. (2018). Pengaruh Budaya Organisasi, Independensi, Kompetensi, Gaya Kepemimpinan dan Profesionalisme Terhadap Kinerja Auditor (Studi Empiris Pada Kantor Akuntan Publik di Surakarta dan Yogyakarta).

Siagian, S. P. (2002). Kepemimpinan Organisasi \& Perilaku Administrasi. Jakarta: Gunung Agung.

Sugianto Yusuf, P., Haizam Mohd Saudi, M., Nurmalasari, T., \& Surayya Mohd Saudi, N. (2018). The Effect of Management Control System and Leadership Style on Managerial Performance (An Empirical Studies on SOE Company in Bandung). International Journal of Engineering \& Technology, 7(4.34), 274. https://doi.org/10.14419/ijet.v7i4.34.25292

Susanto, R. (2015). Pengaruh Good Governance, Pengendalian Intern Komitmen 
Karyawan, dan Pengelolaan Keuangan Daerah Terhadap Kinerja Manajerial Pemerintah Daerah (Studi Empiris Pada Pemerintah Kabupaten Klaten). Retrieved from http:/ / weekly.cnbnews.com/news/article.html?no=124000

Trisnaningsih, S. (2007). Independensi Auditor Dan Komitmen Organisasi Sebagai Mediasi Pengaruh Pemahaman Good Corporate Governance, Gaya Kepemimpinan dan Budaya Organisasi Terhadap Kinerja Auditor. Simposium Nasional Akuntansi X.

Warrick, D. D. (1981). Leadership Styles and Their Consequences. Journal of Experiential Learning and Simulation, 3(4), 155-172.

Wati, E. L., \& Aprilla, N. (2010). Pengaruh Independensi, Gaya Kepemimpinan, Komitmen Organisasi, dan Pemahaman Good Governance Terhadap Kinerja Auditor Pemerintah (Studi Pada Auditor Pemerintah di BPKP Perwakilan Bengkulu). Simposium Nasional Akuntansi (SNA) XIII.

Widasari, K. I., \& Putri, I. G. A. M. A. D. (2018). Pengaruh Good Governance dan Budaya Organisasi Terhadap Kinerja Manajerial Penyelenggara Pemerintahan Desa di Kabupaten Badung. E-Jurnal Akuntansi Universitas Udayana, 22(2), 1308-1334.

Windiarto, R. I. (2015). Analisis Pengaruh Penerapan Prinsip-Prinsip Good Corporate Governance dan Komitmen Organisasi Terhadap Kinerja Aparatur Pemerintahan (Studi Empiris Pada SKPD Kota Surakarta). Naskah Publikasi Fakultas Ekonomi Dan Bisnis Universitas Muhamadiyah Surakarta.

Wiratno, A., Pratiwi, U., \& Nurkhikmah. (2013). Pengaruh Budaya Organisasi, Gaya Kepemimpinan, Komitmen Organisasi dan Pengendalian Intern Terhadap Penerapan Good Governance Serta Implikasinya Pada Kinerja (Survey Pada Kantor Pelayanan Perbendaharaan Negara Tegal). Jurnal Universitas Jenderal Soedirman, 1(1), 1-8.

Yogantara, K. K., \& Wirakusuma, M. G. (2013). Pengaruh Komitmen Organisasi dan Gaya Kepemimpinan Pada Hubungan Antara Partisipasi Anggaran dan Kinerja Manajerial. E-Jurnal Akuntansi Universitas Udayana, 4(2), 563-580. 